\title{
Facies characterisation of a shallow-water deltaic succession: the Upper Jurassic Wagad Sandstone Formation of Kachchh, western India
}

\author{
Jaquilin K. Joseph*, Satish J. Patel \\ Department of Geology, The Maharaja Sayajirao University of Baroda, Vadodara 390 002, Gujarat State, India \\ *corresponding author, e-mail: jaquilinjoseph@gmail.com
}

\begin{abstract}
Ancient deltaic facies are difficult to differentiate from tidally influenced shallow-marine facies. The Wagad Sandstone Formation of the Wagad Highland (eastern Kachchh Basin) is typified by offshore and deltaic facies with sedimentary characteristics that represent different conditions of hydrodynamics and related depositional processes. The study area, the Adhoi Anticline, constitutes a 154 -m-thick, shale-dominated sequence with progressive upward intercalations of bioturbated micritic sandstone and quartz arenite. Two thick Astarte beds (sandy allochemic limestone), with an erosional base and gravel blanketing, illustrate tidal amplification and high-energy stochastic events such as storms. Sedimentological characteristics document three depositional facies: an offshore, shale-dominated sequence prograding to proximal prodeltaic micritic sandstone and quartz arenite with sandy allochemic limestones, further prograding to mouth bars and abandoned channel deposits. The Wagad Sandstone Formation displays depositional environmental conditions that are dissimilar from those of coeval deposits in Kachchh sub-basins as well as on regional and global scales. This is attributed to a reactivation of the Kachchh Mainland and South Wagad faults which resulted in detachment and uplift of the Wagad block which then experienced prograding deltaic conditions.
\end{abstract}

Key words: Lithofacies, Oxfordian-Kimmeridgian, offshore, shallow-water delta, South Wagad Fault

\section{Introduction}

Deltaic systems are basically controlled by river discharge and sediment load and are later reworked by marine processes. Previous studies focused more closely on wave-dominated (Reijers, 2011; Ezeh et al., 2016; Hampson \& Howell, 2017) and river-dominated deltas (Coleman, 1988; Coleman et al., 1998; Hurd et al., 2014; Huang \& Bhattacharya, 2017), while only little attention was paid to tidally dominated/influenced deltas (Fisher et al., 1969; Galloway, 1975; Maguregui \& Tyler, 1991; Harris et al., 1993; Willis \& Gabel, 2001; Dalrymple et al., 2003; Allison et al., 2003; McIlroy, 2004; Higgins et al., 2014).
Upper Jurassic (Oxfordian-Kimmeridgian) strata of the Wagad Highland of eastern Kachchh (India) have long been identified as deltaic deposits (Biswas, 1980). However, sedimentary geometry and facies characterisation of this delta have not been properly considered; therefore, in the present study, the different depositional facies that developed within the delta are interpreted on the basis of sedimentological and palaeontological evidences within the Wagad Sandstone Formation (Wagad Highland, eastern Kachchh, India).The aims of the present study are two-fold: firstly, to understand facies characteristics and establish a sedimentary model of the shallow-water delta, secondly, to differentiate this from the Gilbert-type (deep-water) of deltas. 


\section{Locality and geological setting}

The Wagad region is the most proximal surface exposure of the Jurassic sedimentary succession in the eastern part of the Kachchh Basin. It has been considered a highly strained zone (Rastogi, 2001; Mandal et al., 2004) that is physiographically divided into three divisions, i.e., the Northern Range, the Southern Range and the Kanthkot Range. The present study has been carried out in the Adhoi Anticline, which is an asymmetrical anticline that is positioned between $23^{\circ} 23^{\prime} 39^{\prime \prime} \mathrm{N}$ and $23^{\circ} 24^{\prime} 15^{\prime \prime} \mathrm{N}$ latitude and 70'30'29" $\mathrm{E}$ and $70^{\circ} 34^{\prime} 44^{\prime \prime} \mathrm{E}$ longitude (Fig. 1), in the southern-range subprovinces of the Wagad Highland.

The Kachchh Basin is a pericratonic basin which rifted during the Late Triassic; marine sedimentation started during the Middle Jurassic. These Mesozoic sedimentary rocks comprise an Upper Triassic continental deposit, Jurassic marine deposits and Upper Jurassic-Cretaceous fluvio-deltaic strata (Biswas, 1999). During the rift phase extension, block tilting along the five major faults (Nagar Parkar fault, Island Belt fault, South Wagad fault, Kachchh Mainland fault and North Kathiawar fault) (Fig. 1) gave rise during the Late Jurassic to four subparallel linear ridges, namely the Nagar Parker uplift (NPU), Island Belt uplift (IBU), Wagad uplift (WU) and Kachchh Mainland uplift (KMU) (see Biswas, 1980; Krishna et al., 2009).

Many workers have conducted studies on various aspects in the Wagad region of eastern Kachchh (e.g., Deshpande \& Merh, 1980; Kulkarni \& Ghare, 1989; Krishna et al., 1998, 2009; Mishra \& Biswas, 2009). Biswas (1980, 1993) subdivided the Wagad Sandstone Formation into two members, i.e., the lower Kanthkot Member and upper Gamdau Member. Subsequently, Deshpande \& Merh (1980) raised the Kanthkot and Gamdau members to formation status and introduced three members for the Kanthkot Formation, i.e., the Patasar Shale, Fort Sandstone and Adhoi members. Both the lower and upper limits of the Adhoi Member were marked by Astarte beds. Later, Krishna et al. (2009) assigned the Kanthkot Member and the Gamdau

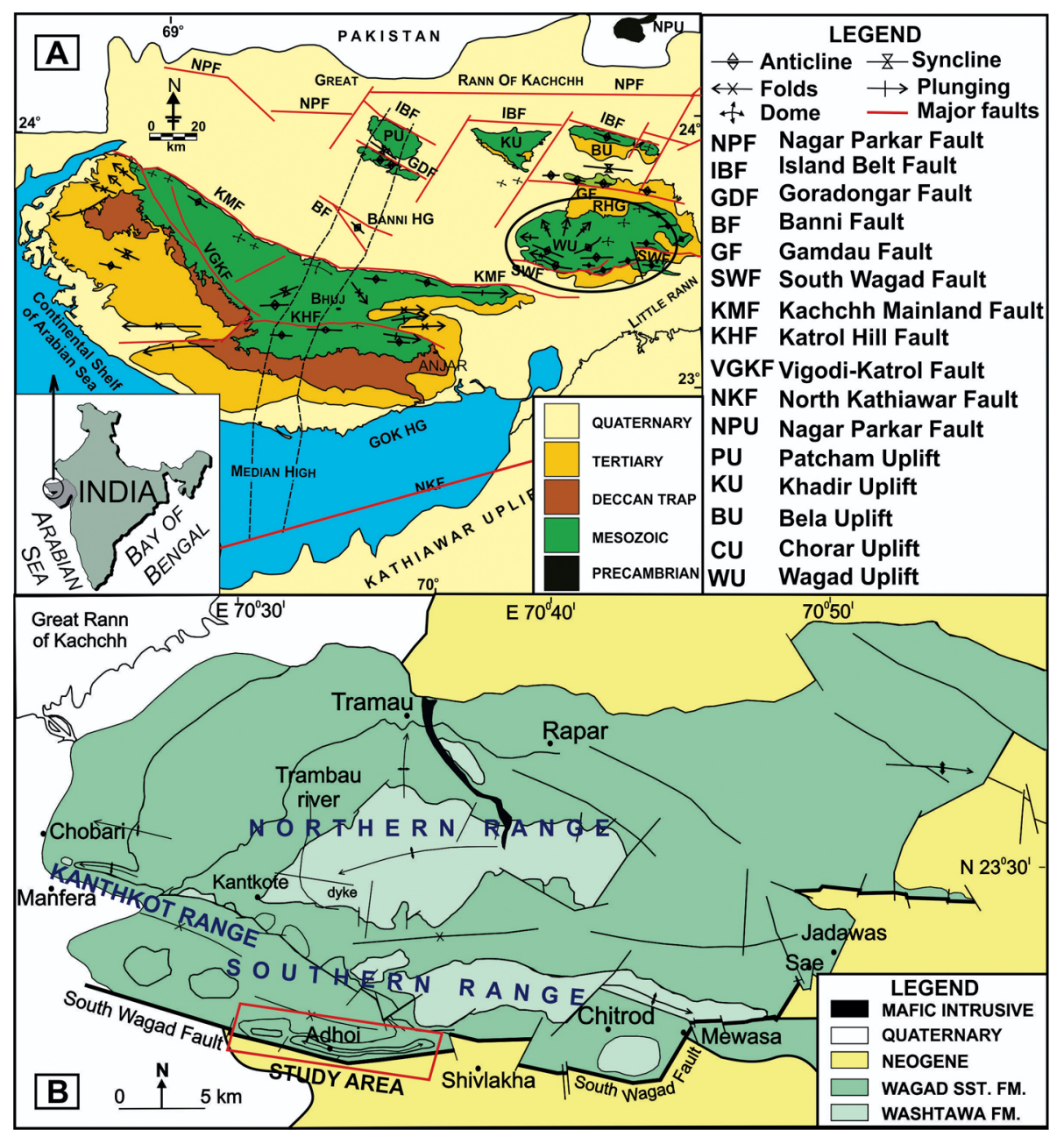

Fig. 1. A - Geological and structural map of the Kachchh Basin (Biswas \& Deshpande, 1970, 1973; Biswas, 1982, 1987), showing the position of the Wagad Highland (black ellipse); B - Detailed geological and structural map of the Wagad Highland (after Rai et al., 2015; Biswas, 2016), showing the location of the Adhoi Anticline (red rectangle). 
Fig. 2. Litholog of the Adhoi Anticline, illustrating sedimentary characteristics, associated body and trace fossils and depositional environments.

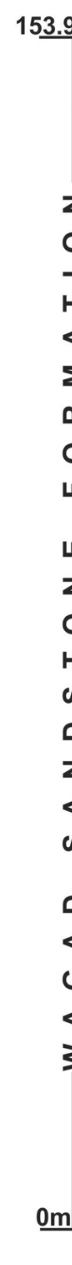

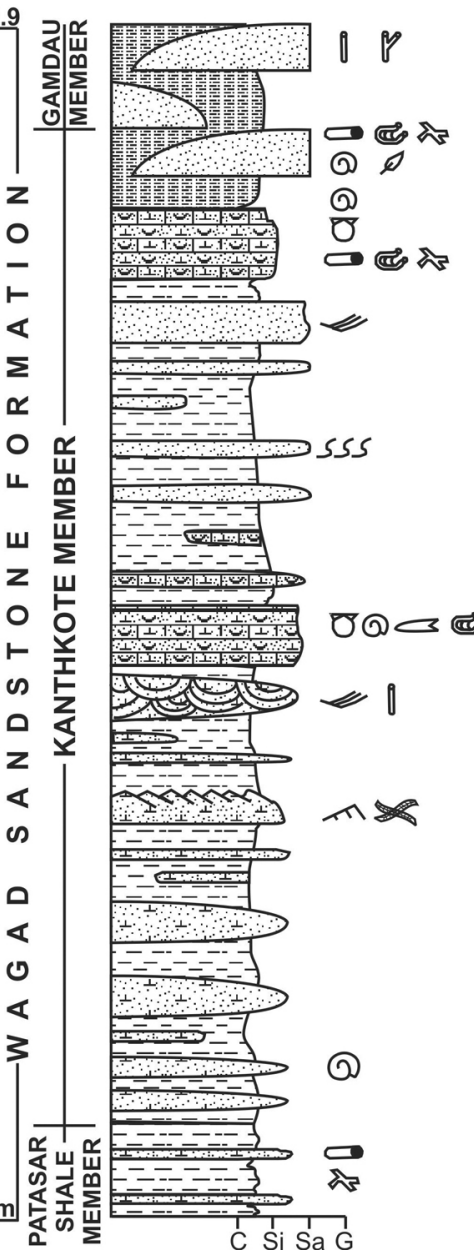

\begin{tabular}{|c|c|}
\hline \multicolumn{2}{|c|}{ LEGEND } \\
\hline$E=$ & Shale \\
\hline 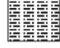 & Mudstone \\
\hline 4 & Micritic sandstone \\
\hline 14 & $\begin{array}{l}\text { Sandy allochem } \\
\text { limestone }\end{array}$ \\
\hline n & Quartz arenite \\
\hline E & Cross-bedding \\
\hline 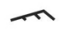 & Ripple marks \\
\hline ๑ & Ammonites \\
\hline$\lessdot$ & Belemnites \\
\hline U & Bivalves \\
\hline$\varnothing$ & Plant fossil \\
\hline 5 & Highly bioturbated \\
\hline 8 & Gyrochortes \\
\hline$\varnothing$ & Palaeophycus \\
\hline Y9 & Polykladichnus \\
\hline త్ర & Rhizocorallium \\
\hline ] & Skolithos \\
\hline జ & Thalassinoides \\
\hline
\end{tabular}

Member to the Katrol and Umia formations, respectively.

Recently, Biswas (2016) revised the lithostratigraphical classification for the Wagad region and adopted the Patasar Shale Member of Deshpande \& Merh (1980) and assigned it to the Wagad Sandstone Formation. Therefore, the Wagad Highland sequence of Callovian to Kimmeridgian (Jurassic) age is now subdivided into two units, i.e., a lower, the Washtawa Formation (Kharol and Nara Shale members) and an upper, the Wagad Sandstone Formation (Patasar Shale, Kanthkot and Gamdau members). In the study area, the Adhoi Anticline, the Wagad Sandstone Formation, which ranges in age from late Oxfordian to Kimmeridgian (Krishna et al., 2009; Biswas, 2016), is exposed. Rai et al. (2015) considered the age of the Patasar Shale Member to be late Oxfordian to early Kimmeridgian on the basis of microplankton groups (nannofossils and dinoflagellates). However, the late Oxfordian date, proposed earlier, as based on ammonites (Krishna et al., 2009), was reconsidered by Krishna (2017).

\section{Lithofacies description}

The Upper Jurassic succession of the Adhoi Anticline comprises $\sim 154$ metres of fine, clast-dominated sedimentary rocks with arenaceous and mixed siliciclastic-carbonate components (Fig. 2). Our field study and petrographic analysis have enabled to discriminate the various rock types that are further classified on the basis of schemes published by Dott (1964), Pettijohn (1949) and Mount (1985). Four distinct rock types are distinguished, namely (1) shale/mudstone, (2) micritic sandstone, (3) sandy allochemic limestone and (4) quartz arenite. The characteristics of each rock type are discussed below.

\subsection{Shale/mudstone}

Shale and mudstone are differentiated on the basis of fissility (Pettijohn, 1949). Shale is amongst the predominant rock types in the Adhoi section, which is mainly calcareous in the lower part; however, it also contains gypsum and is sandy in nature (Patasar 


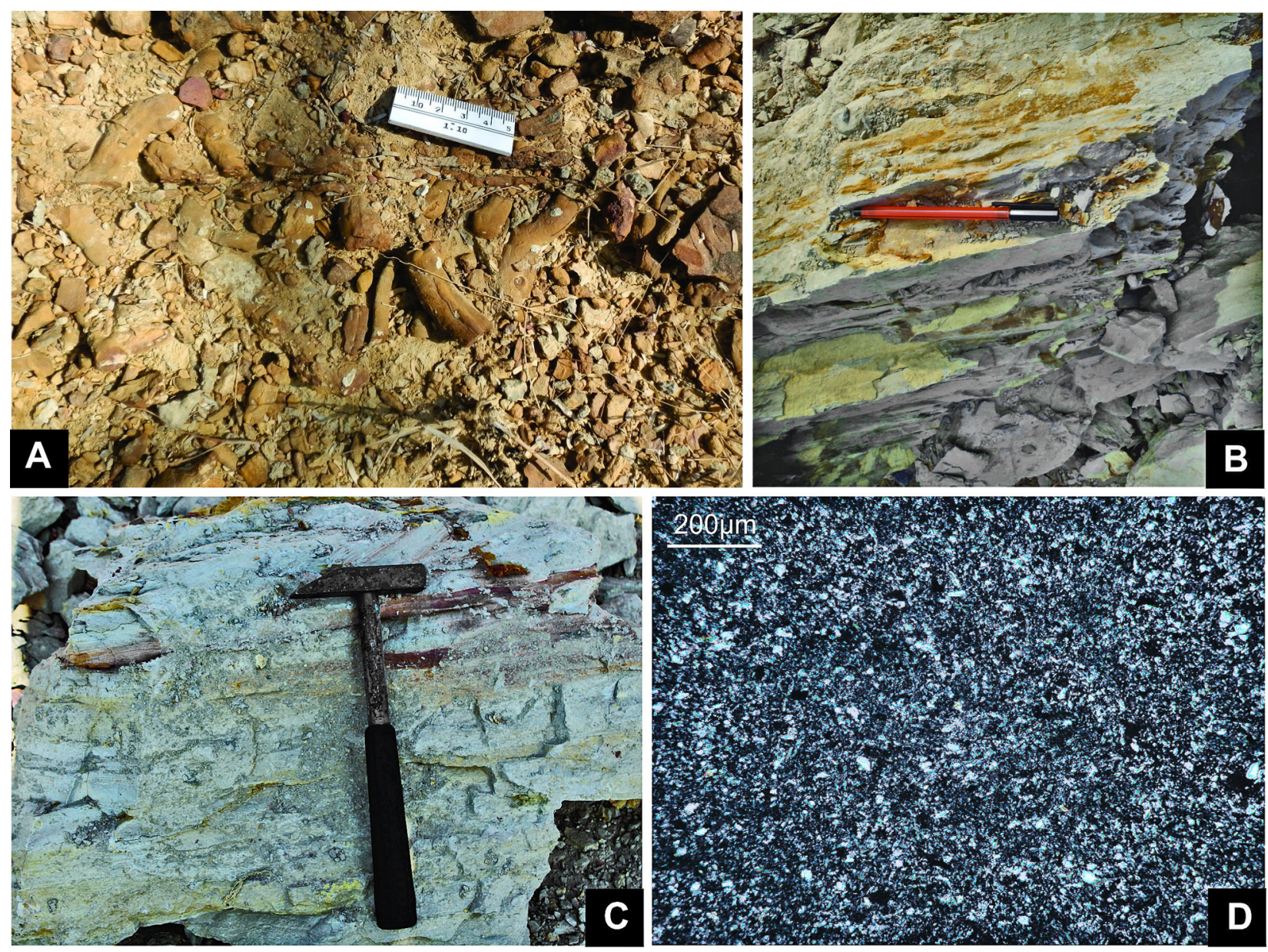

Fig. 3. A - Large-sized Thalassinoides burrows in the shale facies of the Patasar Shale Member (offshore environment); B - White, non-fissile, bedded mudstone of the Gamdau Member, representing mouth bar deposits (length of pen = $14 \mathrm{~cm}$ ); C - Mouth bar deposits, consisting of massive to faintly laminated mudstone of the Gamdau Member (length of hammer $=40 \mathrm{~cm}$ ); D - Silt-sized quartz with fine macerated and clay minerals in the mudstone facies of the Gamdau Member (mouth bar channel).

Shale Member) and becomes argillaceous in the upper part of the sequence of the Wagad Sandstone Formation. It is characterised by off-yellow and grey colours and is often found to intercalate with sandy allochemic limestone, quartz arenite and micritic sandstone. It also contains large-sized Thalassinoides burrows (Fig. 3A) in the Patasar Shale Member. Shale thickness is highly variable. Shale of a maximum thickness of 30 metres, intercalated with 1-m-thick quartz arenite that divides the unit into a number of subunits, is observed in the upper Kanthkot Member, while a minimum thickness (1.1 $\mathrm{m})$ has been documented for the Patasar Shale Member. In the Gamdau Member ( $~ 8 \mathrm{~m}$ thick), a whitish grey in colour, non-fissile, massive to laminated mudstone (Fig. 3B, C) occurs that underlies the highly bioturbated quartz arenite. Petrographically, the mudstone is composed of silt-sized, subangular to subrounded quartz and clay minerals along with some muscovite and heavy minerals (Fig. 3D).

\subsection{Micritic sandstone}

This is of yellow, brown, red and white colours, being intercalated with shale (Fig. 4A) in the Patasar Shale Member and the lower part of the Kanthkot Member. The maximum thickness $(8.16 \mathrm{~m})$ has been measured in the Kanthkot Member, whereas 1-m-thick bands have been noted in the Patasar Shale Member (Fig. 4B). It is also characterised by ripple marks and cross bedding (Fig. 4C) and shows sparse to moderate bioturbation with vertical burrows (Skolithos; Fig. 4D) and horizontal ones: Palaeophycus (Fig. 4E) and Gyrochorte (Fig. 4F) in the Kanthkot Member. Petrographically, this represents a micritic sandstone (Fig. 4G) that consists of subangular to subrounded, fine to medium, poorly to moderately sorted grains of quartz (76-84\%), plagioclase $(1-2 \%)$, microcline $(1-2 \%)$ and rock fragments $(0-3 \%)$ in a micritic cement $(10-20 \%)$. Diagenetic features such as dissolution of quartz due 

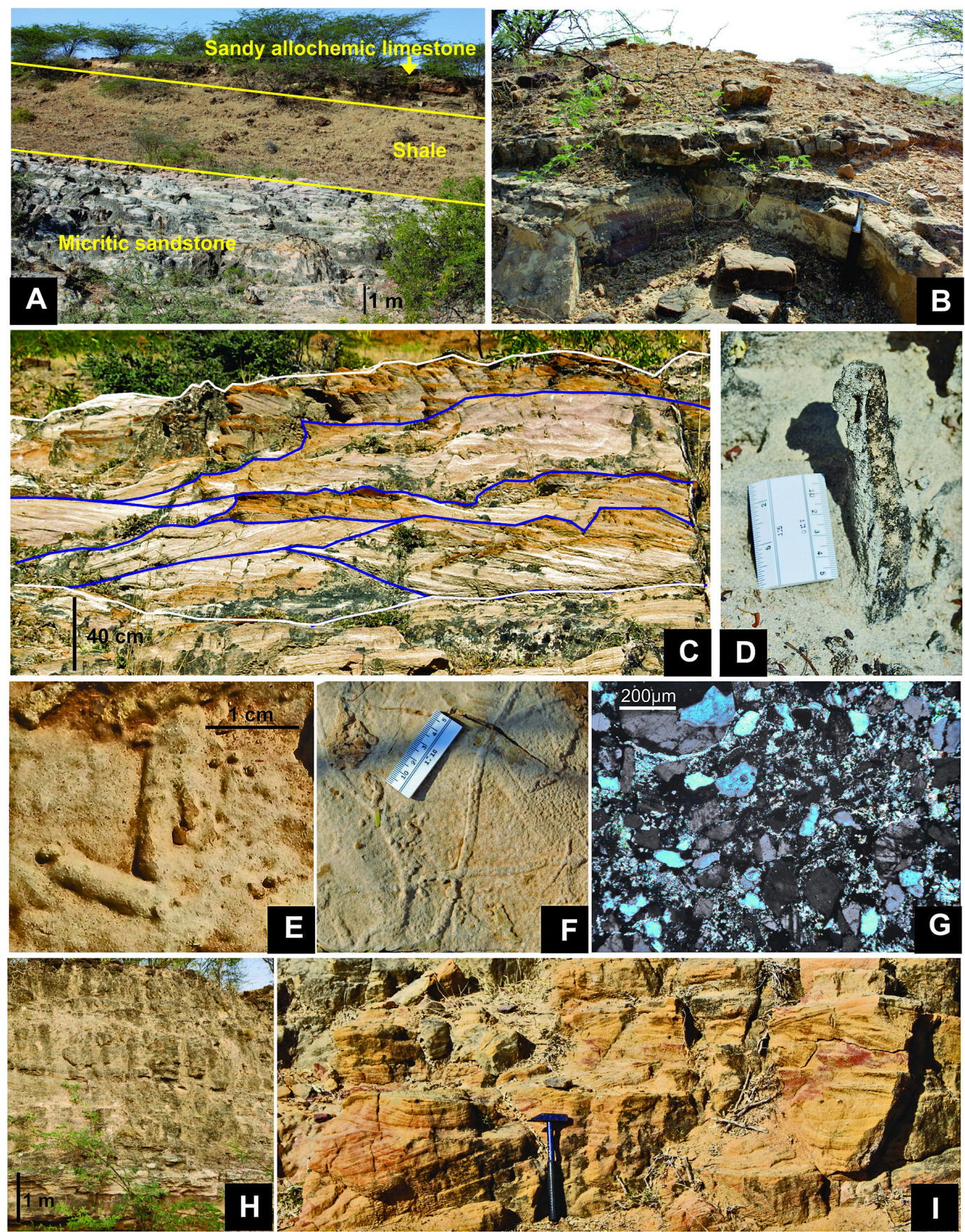

Fig. 4. A - Field view of white-coloured, cross-bedded micritic sandstone overlain by off-yellow shale and sandy allochemic limestone (Upper Astarte Bed) in a prodeltaic environment. Scale bar equals $1 \mathrm{~m}$; B - Metre-thick micritic sandstone beds intercalated with thin calcareous shale beds of the Patasar Shale Member, representing an offshore environment (length of hammer $=40 \mathrm{~cm}$ ); C - Stacked cross-sets with erosional, third-order (blue lines) and fourth-order (white lines) surfaces in white micritic sandstone of the Kanthkot Member; reactivation surfaces are commonly seen in prodeltas; D - Vertical tube of lined Skolithos linearis burrows in white, cross-bedded micritic sandstone of proximal prodelta. Scale bar equals $5 \mathrm{~cm}$; E - Thin-lined Palaeophycus burrows in yellow micritic sandstones of proximal prodeltaic deposits of the Kanthkot Member; F - Cross-over Gyrochorte comosa traces in white, rippled micritic sandstone, proximal prodelta; G - Dissolution of quartz-boundary due to micritisation in medium- to coarse-grained micritic sandstone of the prodelta of the Kanthkot Member; $\mathbf{H}$-Thickening-up of massive to poorly developed cross-sets in quartz arenite intercalated with shaly sandstone layers in the proximal prodelta of the Kanthkot Member observed along the eastern side of the Adhoi Anticline; I - Stacked cross-stratified units in off yellow- to red-coloured quartz arenite, representing proximal prodeltaic conditions of the Kanthkot Member (length of hammer $=40 \mathrm{~cm}$ ). 
to micritisation (Fig. 4G) and/or ferruginisation and breaking of muscovite flakes have also been observed.

\subsection{Sandy allochemic limestone}

This is a yellow, highly fossiliferous limestone that occurs at two different stratigraphical levels with thicknesses of 10 and $9.6 \mathrm{~m}$, respectively; these are popularly referred to as the Lower (Fig. 5A, G) and
Upper Astarte (Fig. 5B) beds, respectively, in the Kanthkot Member of the Wagad Sandstone Formation (Biswas, 1993). These Astarte beds contain mostly disarticulated, convex-up valves of the bivalve Astarte and commonly also yield ammonites (Fig. 5C) and the trace fossil Rhizocorallium (Fig. 5D). The Lower Astarte Bed (Fig. 5G) also yields the bivalve Alectryonia (Fig. 5E) and belemnites (Fig. 5F), while the Upper Astarte Bed contains trace fossils such as Palaeophycus (Fig. 5H), Rhizocorallium and Thalassinoides. Petrographically, it
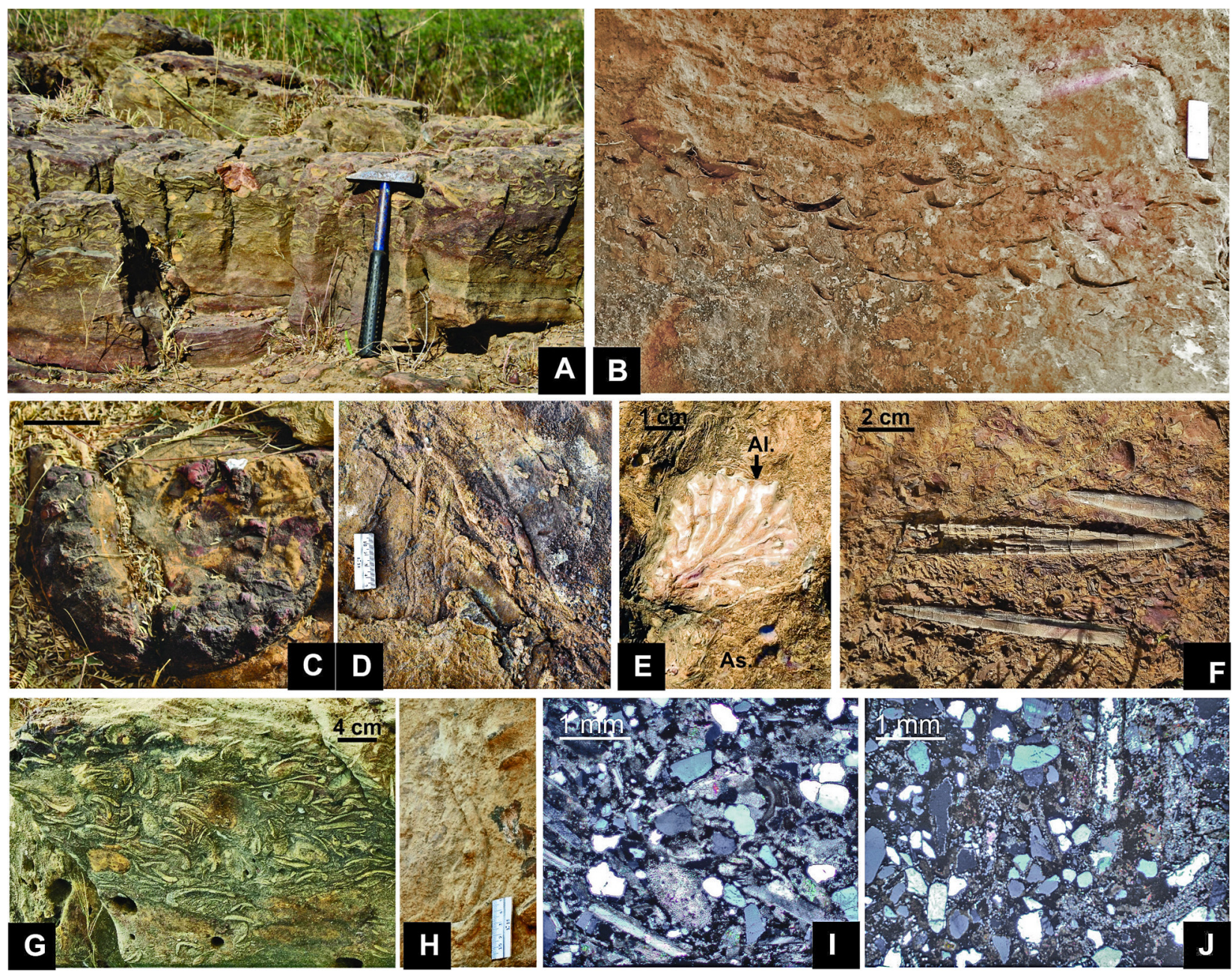

Fig. 5. A - Lower Astarte Bed with shell taphonomy changing laterally from convex-up orientation to disorientation and representing a few shells in butterfly position due to rapid sedimentation after reworking in a storm-dominated proximal prodelta (length of hammer $=40 \mathrm{~cm}$ ); B - Convex-down shell orientation of the Upper Astarte Bed, representing deposition from suspension flow and immediate burial. Scale bar equals $5 \mathrm{~cm}$; C - Ammonite in the Lower Astarte Bed of storm-dominated proximal prodelta of the Kanthkot Member. Scale bar equals $5 \mathrm{~cm}$; D Horizontal, U-shaped spreiten burrow Rhizocorallium in the Upper Astarte Bed of the Kanthkot Member. Scale bar equals $5 \mathrm{~cm}$; E - Disarticulated Astarte (As.) and Alectryonia (Al.) in the Lower Astarte Bed. Scale bar equals $1 \mathrm{~cm}$; F - Large, oriented belemnite guards in the Lower Astarte Bed; G - Disoriented Astarte valves indicating deposition due to rapid settling of traction flow in the Lower Astarte Bed; $\mathbf{H}$ - Lined Palaeophycus burrow in Upper Astarte Bed of storm-dominated proximal prodelta. Scale bar equals $5 \mathrm{~cm}$; I - Abundant bivalve shells, coralline algae and few quartz grains in a micritic matrix, representing sandy allochem limestone of storm-dominated prodelta deposits of the Kanthkot Member; J - Microphotographs showing poorly sorted quartz and feldspar grains and diagenetically altered bioclasts in storm-dominated proximal prodelta strata. 
shows predominantly allochems such as molluscan shells (60-64\%), fragments of coralline algae $(1-2 \%)$, intraclasts $(0-2 \%)$, serially chambered foraminifera $(0-1 \%)$ and micritised concentric ooids $(0-1 \%)$ with fine- to medium-grained, subrounded quartz (12-20\%) in 10 percent micritic cement (Fig. 5I, J).

\subsection{Quartz arenite}

This is a yellowish and reddish brown sandstone, intercalated within shale or mudstone, in the Kanthkot and Gamdau members. It shows cross bedding (Fig. 6A) and moderate bioturbation: Palaeophycus, Rhizocorallium (Fig. 6E) and Thalassinoides in the Kanthkot Member and high bioturbation (Fig. 6B) and mainly vertical burrows of Skolithos and Polykladichnus types (Fig. 6C) in the Gamdau Member. In the Kanthkot Member, this quartz arenite also yields ammonites and plant remains (Fig. 6D). A 6-m-thick (maximum) bed of quartz arenite has been noted in the Gamdau Member, whereas 1-m-thick (minimum) beds can be observed in the Kanthkot Member.
Petrographically, the quartz arenite contains medium to coarse-grained, subangular to angular, poorly to moderately sorted quartz $(91 \%)$, plagioclase $(0-1 \%)$, microcline $(0-1 \%)$ and rock fragments $(0-2 \%)$ in a siliceous matrix $(<15 \%)$. Sutured quartz boundaries show a dissolution phenomenon caused by alkaline solution and subsequent infill by ferruginous materials, while broken muscovite flakes are indicative of the effects of post-depositional pressure solution.

\section{Facies interpretation}

Sedimentological and palaeontological investigations in the Adhoi anticline have revealed a 154-m-thick sequence that consists of micritic sandstone, sandy allochemic limestone, quartz arenite and shale/mudstone. These major rock type associations that document different depositional settings of the Wagad Sandstone Formation can be grouped, broad scale, into two environmental facies, namely offshore and shallow-water delta. Sedimentary characteristics, together with vertical and lateral continuity of the beds, have been used
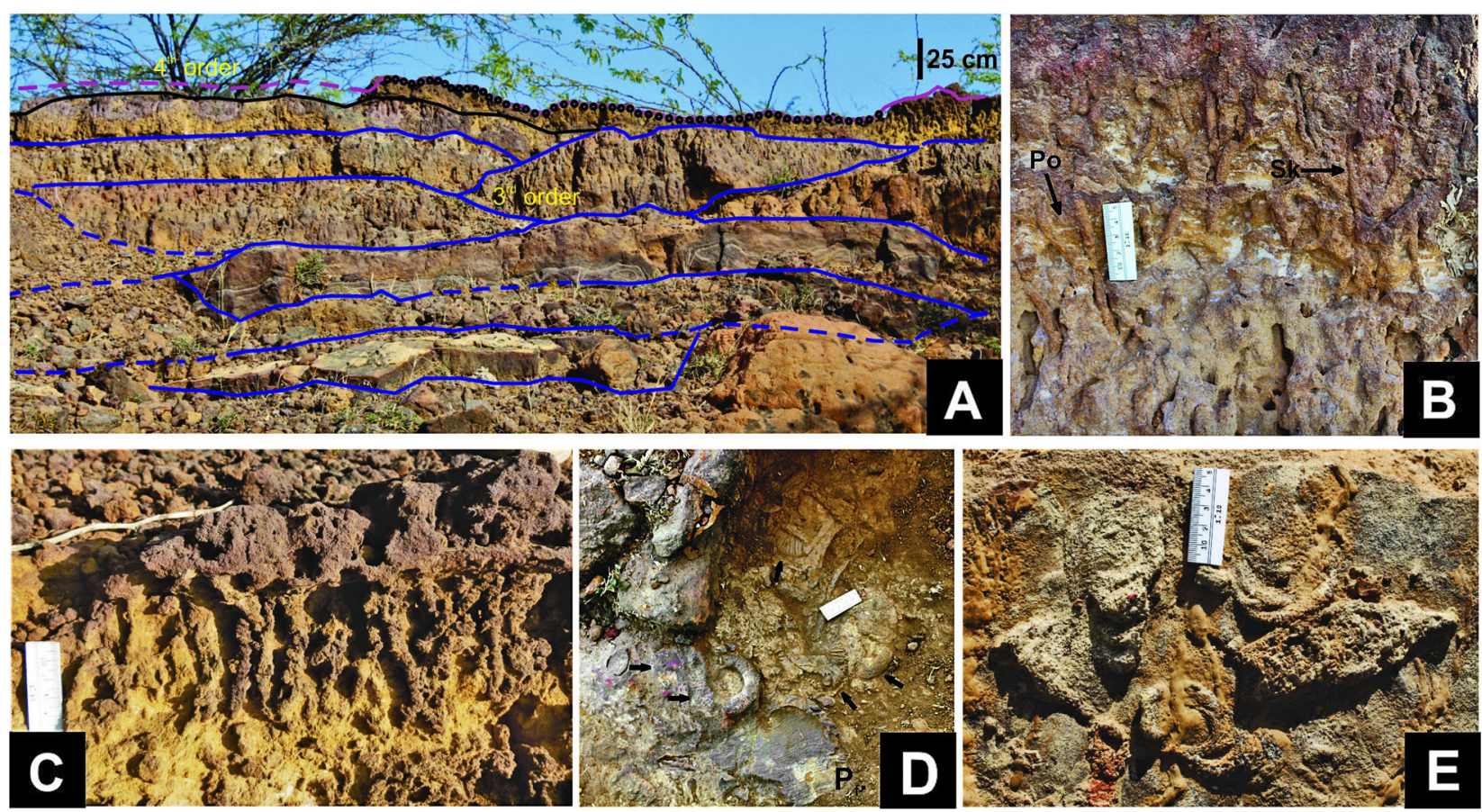

Fig. 6. A - Bioturbated cross-bedded quartz arenite showing lens with convex-up, third-order internal erosion surface (blue lines) and upper, fourth-order bounding surfaces (purple lines) representing mouth bars; B - Densely packed Skolithos linearis (Sk) and Polykladichnus irregularis (Po) burrows, obliterating physical sedimentary structures in mouth bar deposit. Scale bar equals $5 \mathrm{~cm}$; C - Densely packed, collapsed Polykladichnus irregularis burrows in red-coloured quartz arenite of mouth bar deposit. Note: relief of the burrows is due to weathering and erosion. Scale bar equals $5 \mathrm{~cm}$; D - Abundant ammonites (arrowed) and plant remains $\left(\mathrm{P}_{\mathrm{f}}\right)$ embedded in red quartz arenite of the Kanthkot Member. Scale bar equals $5 \mathrm{~cm}$; E - Vertically retrusive U-shaped spreiten of Rhizocorallium problematica in the red-coloured quartz arenite of the Kanthkot Member. Scale bar equals $5 \mathrm{~cm}$. 


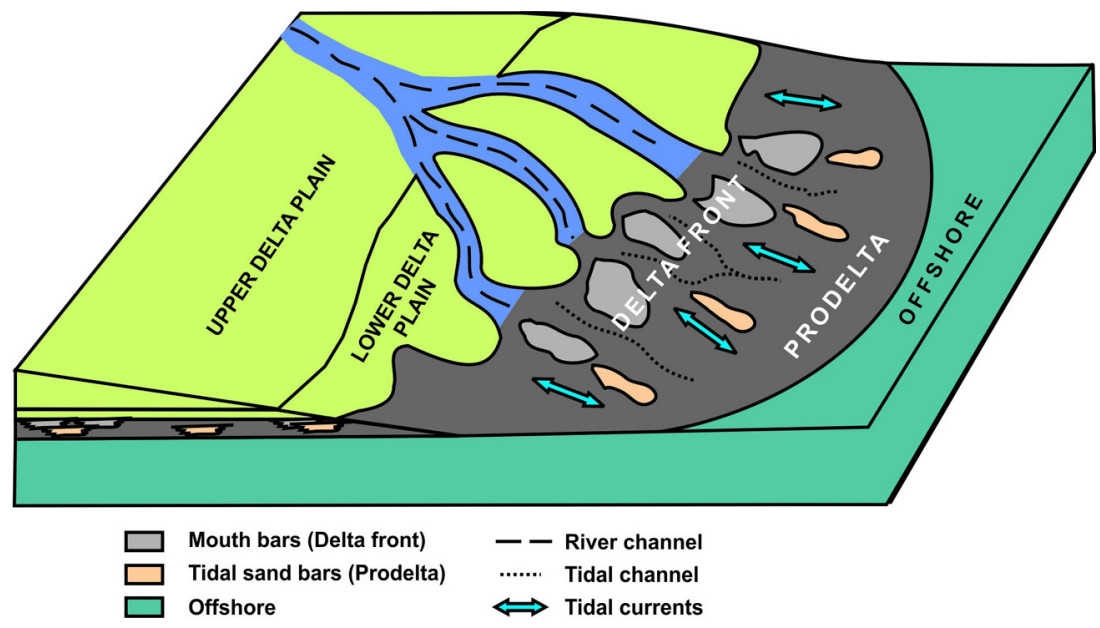

Fig. 7. Reconstructed 3-D model of the Wagad Sandstone Formation (Oxfordian to Kimmeridgian) in the Wagad Highland, depicting offshore and shallow-water delta (prodelta and delta front) environments.

to identify the depositional settings of each facies. These are discussed below and also represented schematically in Figure 7.

\subsection{Offshore facies}

Off-yellow gypseous sandy shales interbedded with thickening-up and coarsening-up micritic sandstone beds, represent the offshore facies. This has been observed in the Patasar Shale Member (Wagad Sandstone Formation), where the lower part of this facies predominantly consists of shale with fine- to medium-grained, thin micritic sandstone $(2-5 \mathrm{~cm})$ beds. The micritic sandstones interbedded with off yellow shales are fissile to flaggy in nature. However, the upper part shows medium- to coarse-grained, poorly sorted, 2-m-thick micritic sandstone beds, interbedded with thin sandy shale beds (Fig. 4B). The micritic sandstone shows wavy bedding in the upper part of the sequence, where it predominates over shale. The flaggy and wavy nature of the micritic sandstone is indicative of the oscillatory wave movements that dominated over current waves in the offshore regions. The thickening-up sequence represents a prograding coastline.

This facies comprises Palaeophycus heberti and large, thick-lined Thalassinoides isp. (Fig. 3A) burrows in micritic sandstone and the lower shale unit, respectively. Palaeophycus is the dwelling burrow of predaceous or suspension-feeding organisms (Pemberton \&Frey, 1982), while Thalassinoides is generally interpreted as dwelling and feeding structures of decapod crustaceans (Frey et al., 1984). Burrows of the Palaeophycus and Thalassinoides types are archetypal of the Cruziana Ichnofacies that is commonly reported from offshore environments (e.g., Bann \& Fielding, 2004) and developed in soft sediments.

\subsection{Shallow-water delta facies}

This facies illustrates a proximal prodelta with storm-dominated deposits and a delta front with mouth bars and abandoned channel deposits. The proximal prodelta deposits enclose intercalated deposits consisting of shales with yellowish red to white micritic sandstone in the lower part and quartz arenite in the upper part of the sequence. There are also two thick, yellow, fossiliferous sandy allochemic limestone beds enclosed in this facies; these represent storm-dominated deposits in the proximal prodelta. The delta front deposits of mouth bars and mouth bar channels are characterised by red-coloured quartz arenites, interbedded with white mudstone.

\subsubsection{Proximal prodelta deposits}

Proximal prodelta deposits consist of a shale-dominated succession with 10-m-thick, white to red-coloured micritic sandstones and 5-m-thick, hard, reddish brown quartz arenite. The lower part of the sequence shows red-coloured micritic sandstone beds with ripple marks and Gyrochorte comosa Fig. 4F), as well as white, cross-bedded micritic sandstone beds (Fig. 4A, C) with Skolithos linearis (Fig. 4D).This unit, characterised by a lower diversity suite of trace fossils, shows a sporadically distributed stressed Cruziana Ichnofacies and a mixture of elements that are characteristic of the Skolithos and Cruziana Ichnofacies which represent proximal prodeltas (Bann \& Fielding, 2004; Hansen $\&$ MacEachern, 2007). The upper part of the sequence, representing proximal prodeltaic deposits, shows a bioturbated, black sandstone that is overlain by cross-bedded, red to brown, quartz arenite, which documents an increase in siliciclastic influx. This cross-bedded sandstone is 6-m-thick in the east (Fig. $4 \mathrm{H}$ ), while it pinches out to about 3-m in the 
west (Fig. 4I). The lens-shaped bed geometry represents a prograding mouth bar or a detached bar in the prodelta (Ahmed et al., 2014).

\subsubsection{Storm-dominated proximal prodelta deposits}

The storm-dominated deposits are characterised by two thick beds of a mixed siliciclastic-carbonate sediment that represents a sandy allochemic limestone (Fig. 5A, C), intercalated with greyish shale with an erosive bedding surface. The lower sandy allochemic limestone (Fig. 5A) shows abundant bivalves (Astarte and Alectryonia), cephalopods such as ammonites (Fig. 5C) and belemnites (Fig. 5F), as well as trace fossils such as Rhizocorallium commune (Fig. 5D). Rhizocorallium commune occurs frequently as post-event trace fossil in association with storm deposits (Jensen, 1997; Gluszek, 1998; Worsley \& Mørk, 2001; Bann et al., 2004). It has also been recorded from marginal marine settings such as deltas, estuaries, tidal flats and lagoons (e.g., Archer \& Maples, 1984; Clark et al., 2004; De Carvalho et al., 2010; Buatois \& Mángano, 2011) and prodeltas (Jansa, 1972). The upper sandy allochemic limestone shows abundant specimens of Astarte (Fig. 5G) and trace fossils such as Palaeophycus tubularis (Fig. 5H), Rhizocorallium commune and Thalassinoides horizontalis. These sediments with bivalves, ammonites and belemnites of offshore origin were mobilised during high-energy events and redeposited in the prodelta region.

Shell (Astarte) arrangement in the lower sandy allochemic limestone appears to change laterally and vertically from convex-up to disoriented shells (Fig. 5A, G). The distinct convex-up shell pavements and taphonomic signature of the loss of shell ornament and considerable breakage indicates that the shelly remains must have undergone transport by currents (Fürsich \& Oschmann, 1993). The disoriented shell arrangements within the shell beds (Fig. 5G) are indicative of rapid deposition from traction flows which represent episodic toppling and reworking by high-energy events (Sanders et al., 2007). Resumed sedimentation following each reworking interval was very rapid as is indicated by the presence of shells that show a few convex-up and convex-down shells in butterfly position (Simões \& Kowalewski, 1998).

Shells in the upper sandy allochemic limestone are preferentially oriented in convex-down position, which indicates rapid sedimentation from suspension and no subsequent reworking due to immediate burial (Fig. 5B). These thick beds show an abrupt increase in carbonate content and bioclast fragments, an association of preferentially oriented (convex-up) Astarte shells with Alectryonia, ammonites and belemnites, which indicates that it was formed by storm-flow processes within littoral environments. The erosive upper bedding surface of the shale indicates abrasion of the sea floor during the start of a high-energy event such as a storm, which is indicative of an inner zone in a prodelta setting.

\subsubsection{Delta front, mouth bars and abandoned channel facies}

Red-coloured quartz arenite, interbedded with white mudstone, characterises this facies which represents a delta front. The internal geometry shows a lens resting on a flat base with convex-up, third-order internal erosion surfaces and upper, fourth-order bounding surfaces (Fig. 6A), which indicates a mouth bar (Miall, 2006) in a delta front environment. The near-horizontal lower boundary of the beds indicates either a distal or a lateral position towards the margins of the mouth bar, but the presence of trough cross-bedded sandstone and sediment homogeneity are indicative of a proximal mouth bar in a lateral position towards the mouth bar margins of a delta front (Schomacker et al., 2010; Zhu et al., 2017).

The upper quartz arenite package records a composite mouth bar and laterally displays moderate to high bioturbation of Skolithos linearis and Polykladichnus irregularis (Fig. 6B, C). However, the lower package shows quartz arenite with a flat erosive base and third-order internal erosion surfaces. It yields ammonites and plant remains (Fig. 6D) with gravel blanketing and Rhizocorallium problematica (Fig. 6E) observed in the uppermost bed of the sequence.

Skolithos and Polykladichnus are elements of the Skolithos Ichnofacies which is developed in wave(Vossler \& Pemberton, 1988) and tide-dominated (Mángano \& Buatois, 1999, 2004) shorelines as well as marginal marine (MacEachern et al., 2007) and deep-marine turbidite systems (Crimes, 1977). However, the Skolithos Ichnofacies in marginal marine settings (e.g., mouth bars) shows a lower diversity than their fully marine counterparts as a result of the stress linked to salinity fluctuations and water turbidity (Buatois \& Mángano, 2011). The quartz arenite facies of the Gamdau Member consists chiefly of a low diversity but high density of Skolithos and Polykladichnus (Fig. 6B, C) burrows with vertical traits that reflect high-energy, shifting substrate conditions of mouth bars (e.g., Canale et al., 2016). In the lower quartz arenite bed, the vertically retrusive spreiten structure of Rhizocorallium problematica illustrates the response of the producing organism 
A

DEEP WATER DELTA WITH WEAK STORM AND TIDE INFLUENCE

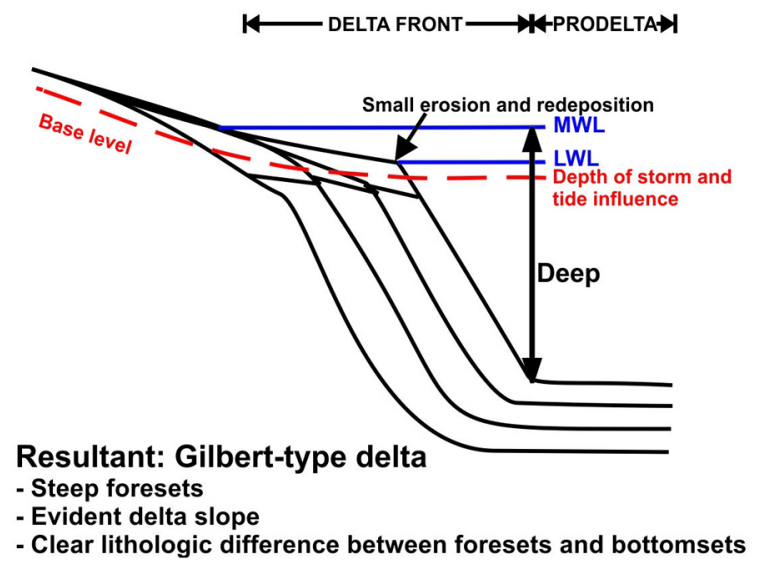

B

SHALLOW WATER DELTA WITH EXTENSIVE STORM AND TIDE INFLUENCE

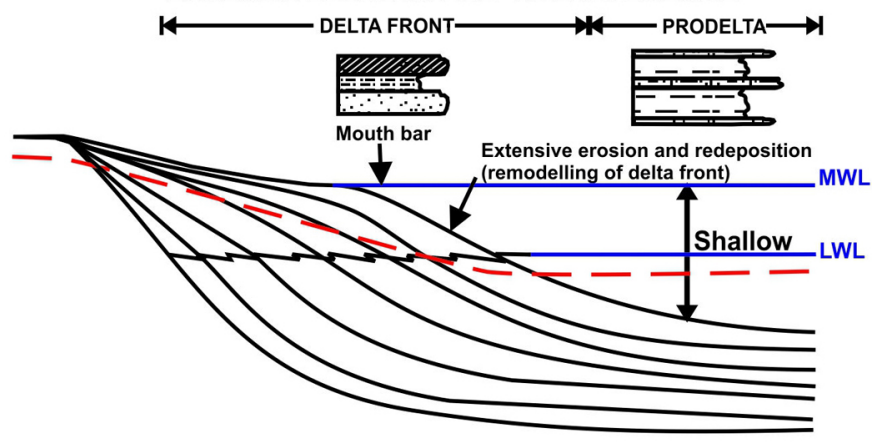

Resultant: Delta scale muddy subaqueous fan - Gentle foresets gradually pass into bottomsets - No evident delta slope

- Discrete lithologic difference between deltaic subenvironments

Fig. 8. Schematic diagram illustrating difference in dip and depth of clinoforms (foreset and bottom set) in: A - Gilbert-type delta; B - Shallow-water delta. This is characterised by low-sloped delta front with continuous passage to prodelta. MWL - maximum water level, LWL - low water level.

to the deposition of suspended material after cessation of sedimentation under powerful flow (Knaust, 2013). The high-energy event and resultant tidal amplification can be envisaged for the quartz arenite on the basis of a co-occurrence of stenohaline organisms (ammonites) and remains of terrestrial plants and gravel blanketing within the mouth bar.

Mudstone lithosomes that consist predominantly of laminated, compact (non-fissile) and indurated clay beds (Fig. 3B) have been observed to be interbedded with the quartz arenites. The internal geometry of the bed is either massive or with remnant cross bedding (Fig. 3C). It consists of clay minerals, silts and sparsely macerated organic matters (Fig. 3D). The maximum observed thickness of the bed is $5 \mathrm{~m}$; it shows an erosional upper contact and scoured basal contact with the quartz arenites. Mud accumulations within the delta usually are attributed to conditions that are prevalent in abandoned distributary channels, interdistributary bays, tidal flats and tidal channels (Van Straaten \& Kuenen, 1958; Harris et al., 1993). The mudstone package of present study area indicates an abandoned distributary channel, where non-regular, through-flow connectivity with the main channel did not result in entrainment of bedload and slow sedimentation of a high amount of suspended load (Gray et al., 2016).

\section{Discussion}

Deposits of the Patasar and Kanthkot members was been interpreted as typical of shallow-marine environments, and the Gamdau Member as a prodeltaic environment by Biswas (1993). How- ever, in the present study, the Patasar Shale Member is considered to represent an offshore deposit which is overlain by prodelta deposits of the Kanthkot Member and delta front deposits of the Gamdau Member.

Generally, the sand-mud ratio is considered to be higher in shoreface environments, with the exception of the offshore region, while it is lower in deltaic settings, except for mouth bars and sand ridges. The present study area shows a lower sand-mud ratio, characterised by predominant shale, with sand units of mouth bars and sand ridges. The bioturbation index (BI) in the Kanthkot Member generally is 1 with a few beds with BI between 3 and 4, which indicates a high sedimentation rate of a prodeltaic setting, rather than the low sedimentation environment of the offshore (Coates \& MacEachern, 2000). The trace fossil elements that predominantly represent a stressed Cruziana Ichnofacies suggest a deltaic origin (Hansen \& MacEachern, 2007). The storm-dominated deposits within the prodeltaic deposits of the Kanthkot Member sequence indicate an open sea with frequent storms, which is similar to the classification scheme of Daidu et al. (2013) for a tide-dominated delta. The alternating sand-mud layers with two thick Astarte beds, as well as ammonites and/or belemnites at different stratigraphical levels, shales with erosional surfaces and gravel blanketing indicate tidal amplification, high-energy stochastic events and sediment budget controls in the deltaic environment that came into existence in what is now the Wagad Sandstone Formation.

In the present study, the sedimentological characteristics of each facies indicate deposition in an offshore to deltaic environment. The deltaic depos- 
its of the Wagad Sandstone Formation show an indistinguishable delta slope which indicates that it is not a true delta, i.e., of the Gilbert-type, with a steep foreset and bottomset, but rather represents a delta-scale, muddy subaqueous fan delta that developed in shallow water (Patruno et al., 2015). The delta front is remodelled by extensive erosion and redeposition due to storms and high tide conditions (Fig. 8) in shallow-marine environments, where basin dynamics drive sediment advection (Patruno et al., 2015). These subaqueous, delta-scale deposits form due to offshore currents and tidal currents which extensively redistribute the deposits brought by the river parallel to the coast and sustain overall growth and progradation of the subaqueous delta. Thus, the offshore current influences the overall shore-parallel strike direction of the subaqueous clinoforms but also controls the position of bottomsets which force deposition along strike direction rather than offshore (Cattaneo et al., 2003, 2007; Liu et al., 2006, 2007; Patruno et al., 2015).

The Upper Oxfordian to Lower Kimmeridgian of the Kachchh Mainland is represented by a hiatus directly following the Dhosa conglomeratic bed (Alberti et al., 2013). However, the Kimmeridgian strata of the Jhuran Formation of Kachchh Mainland, which are coeval to the Wagad Sandstone Formation of the Wagad Highland, represent a fully marine environment. The Oxfordian-Kimmeridgian Jaisalmer and Baisakhi formations in the adjacent Jaisalmer Basin of Rajasthan also represent a marine environment (Singh, 2006), albeit are similar to the Kachchh Mainland. In the Higher Himalayas, the Middle Oxfordian to at least the Lower Kimmeridgian interval is unrecorded; it has been interpreted as a submarine gap (Krishna, 2017).

The non-evident delta slope and different environmental conditions experienced by deposits of the Wagad Sandstone Formation during the Late Oxfordian and Kimmeridgian, in comparison to other areas in India (Singh, 2006; Krishna, 2017) are attributed to increased tectonic activity, which resulted in the subdivision of the Kachchh Basin into several sub-basins, including the Wagad Highland (Biswas, 1993). The subdivision and detachment of the Wagad Highland from Mainland Kachchh is considered to be linked to reactivation of the Kachchh Mainland Fault and South Wagad Fault (Fig. 1) during the Late Jurassic (Biswas, 1993; Krishna et al., 2009). Sequentially, it resulted in local uplift of the Wagad block which led to progradation of tide-dominated deltaic conditions that are responsible for the overall hydrodynamic and sedimentary processes during deposition of the Wagad Sandstone Formation.

\section{Conclusions}

The facies characteristics of the Wagad Sandstone Formation of the Wagad Highland (eastern Kachchh) have been analysed and the following conclusions have been drawn:

1. The Adhoi anticline exposes a 154-m-thick sequence of the Wagad Sandstone Formation, comprising intercalated, mixed siliciclastic carbonates, quartz arenite and shale/mudstone.

2. The shale-dominated deposit of the Patasar Shale Member, characterised by fissile to flaggy and wavy-bedded micritic sandstones with erosional bedding surface formed in an offshore environment during the Oxfordian.

3. The Kanthkot Member (Upper Oxfordian to Middle Kimmeridgian) consists of prodelta deposits with Astarte-rich, sandy allochemic limestone with distinct convex-up shell pavements and taphonomic signatures such as loss of shell ornament and considerable breakage indicative of high-energy stochastic events (storms). The taphonomy of the shells also indicates episodic toppling, reworking and rapidly resumed sedimentation.

4. Lithofacies data, coupled with Rhizocorallium commune and $R$. problematica of the Kanthkot Member, have revealed prodelta to delta front (mouth bar) environments in a shallow-water delta.

5. The macerated plant remains in mudstone, abundant vertical burrows of Skolithos and Polykladichnus and redeposited ammonites in quartz arenite strata of the Gamdau Member (Middle Kimmeridgian) indicates abandoned channels and mouth bars of a delta environment.

6. Previous regional studies have considered the Patasar Shale and Kanthkot members to reflect shallow-marine environments and the Gamdau Member a prodeltaic setting; however, in the present paper the first-named is shown to indicate offshore deposits, the second to be prodeltaic and the Gamdau Member to represent delta front deposits.

7. The present study of the Wagad Sandstone Formation exhibits a clear lateral facies transition from offshore to deltaic environments.

8. The deltaic deposits are not developed as true Gilbert-type delta, but rather indicate a delta-scale, muddy subaqueous fan delta that formed in shallow-water with an indistinguishable delta slope and a remodelled delta front.

9. The uplift of the Wagad Highland, due to the reactivation of major faults during the Late $\mathrm{Ju}$ rassic, governed hydrodynamic and sedimen- 
tary processes that led to the development of well-identified prodelta and delta front deposits under shallow-water deltaic conditions.

\section{Acknowledgments}

We are grateful to anonymous reviewers for their extremely helpful suggestions and comments on an early version of the typescript. One of us (JKJ) thanks the Research Cell and Consultancy (RCC/ Dir./2015/217/9, dated 9/11/2015) of The Maharaja Sayajirao University of Baroda for financial support.

\section{References}

Ahmed, S., Bhattacharya, J.P., Garza, D.E. \& Li, Y., 2014. Facies architecture and stratigraphic evolution of a river-dominated delta front, Turonian Ferron Sandstone, Utah, USA. Journal of Sedimentary Research 84, 97-121.

Alberti, M., Nützel, A., Fürsich, F.T. \& Pandey D.K., 2013. Oxfordian (Late Jurassic) gastropods from the Kachchh Basin, western India. Neues Jahrbuch für Geologie und Paläontologie-Abhandlungen 270, 275-300.

Allison, M.A., Khan, S.R., Goodbred, S.L. \& Kuehl, S.A., 2003. Stratigraphic evolution of the late Holocene Ganges-Brahmaputra lower delta plain. Sedimentary Geology 155, 317-342.

Archer, A.W. \& Maples, C.G. 1984. Trace-fossil distribution across a marine-to-nonmarine gradient in the Pennsylvanian of southwestern Indiana. Journal of Paleontology 58, 448-466.

Bann, K.L. \& Fielding, C.R., 2004. An integrated ichnological and sedimentological comparison of non-deltaic shoreface and subaqueous delta deposits in Permian reservoir units of Australia. [In:] McIlroy, D. (Ed.): The application of ichnology to palaeoenvironmental and stratigraphic Analysis, Geological Society of London, Special Publication 228, 273-307.

Bann, K.L., Fielding, C.R., MacEachern, J.A. \& Tye, S.C., 2004. Differentiation of estuarine and offshore marine deposits using integrated ichnology and sedimentology: Permian Pebbley Beach Formation, Sydney Basin, Australia. Geological Society of London, Special Publications 228, 179-211.

Biswas, S.K., 1980. Mesozoic rock-stratigraphy of Kutch, Gujarat. Quarterly Journal of the Geological, Mining and Metallurgical Society of India 49, 1-52.

Biswas, S.K., 1982. Rift basins in western margin of India and their hydrocarbon prospects with special reference to Kutch Basin. Bulletin of American Association of Petroleum Geologists 66, 1497-1513.

Biswas, S.K., 1987. Regional tectonic framework, structure and evolution of the western marginal basins of India. Tectonophysics 135, 307-327.
Biswas, S.K., 1993. Geology of Kutch. KDM Institute of Petroleum Exploration, Dehradun. 450 pp.

Biswas, S.K., 1999. A Review on the evolution of rift basins in India during Gondwana with special reference to Western Indian basins and their hydrocarbon prospects. [In:] A. Sahni \& R.S. Loyal (Eds): Gondwana Assembly: New Issues and Perspectives. Indian National Science Academy, New Delhi, 53-76pp.

Biswas, S.K., 2016. Mesozoic and Tertiary Stratigraphy of Kutch(Kachchh) - A Review. [In:] M.G. Thakkar (Ed.): Recent Studies on the Geology of Kachchh. Geological Society of India Special Publication 6, 1-24.

Biswas, S.K. \& Deshpande, S.V., 1970. Geological and Tectonic Maps of Kutch. Bulletin of the Oil E Natural Gas Commission 7, 115-116.

Biswas, S.K. \& Deshpande, S.V., 1973. A note on the mode of eruption of the Deccan Trap lavas with special reference to Kutch. Journal of Geological Society of India 14, 134-141.

Buatois, L.A., \& Mángano, M.G., 2011. Ichnology: Organism-substrate interactions in space and time. Cambridge University Press, 357 pp.

Canale, N., Ponce, J.J., Carmona, N.B. \& Drittanti, D.I., 2016. Ichnology of deltaic mouth-bar systems of the Lajas Formation (Middle Jurassic) in the Sierra de la VacaMuerta, Neuquén Basin, Argentina. Ameghiniana 53, 170-183.

Cattaneo, A., Correggiari, A., Langone, L. \& Trincardi, F. 2003. The late-Holocene Gargano subaqueous delta, Adriatic shelf: sediment pathways and supply fluctuations. Marine Geology 193, 61-91.

Cattaneo, A., Trincardi, F., Asioli, A. \& Correggiari, A., 2007. The Western Adriatic shelf clinoform: energy-limited bottomset. Continental Shelf Research 27, 506-525.

Clark, N.D.L., Booth, P., Booth, C. \& Ross, D.A., 2004. Dinosaur footprints from the Duntulm Formation (Bathonian, Jurassic) of the Isle of Skye. Scottish Journal of Geology 40, 13-21.

Coates, L. \& MacEachern, J.A., 2000. Integrating ichnology and sedimentology to differentiate between river-dominated deltas, wave-dominated deltas and shorefaces: examples from the Cretaceous of Western Canada. Geological Society of America, Cordilleran Section, $96^{\text {th }}$ Annual Meeting. Vancouver, 32, A7.

Coleman, J.M., 1988. Dynamic changes and processes in the Mississippi River delta. Geological Society of America Bulletin 100, 999-1015.

Coleman, J.M., Roberts, H.H. \& Stone, G.W., 1998. Mississippi River delta: an overview. Journal of Coastal Research 14, 698-716.

Crimes, T.P., 1977. Trace fossils of an Eocene deep-sea fan, northern Spain. [In:] Crimes, T.P., \& Harper, J.C. (Eds): Trace fossils. Geological Journal, Special issue 9, 71-90.

Daidu, F., Yuan, W. \& Min, L., 2013. Classifications, sedimentary features and facies associations of tidal flats. Journal of Palaeogeography 2, 66-80.

Dalrymple, R.W., Baker, E.K., Harris, P.T. \& Hughes, M.G., 2003. Sedimentology and stratigraphy of a tide-dominated, foreland-basin delta (Fly River, Pap- 
ua New Guinea). [In:] F.H. Sidi, D. Nummedal, P. Imbert , H. Darman \& H.W. Posamentier (Eds): Tropical Deltas of Southeast Asia-Sedimentology, Stratigraphy and Petroleum Geology, Society of Economic Paleontologists and Mineralogists, Special Publication 76, 147-173.

De Carvalho, C.N., Rodrigues, N.P., Viegas, P.A., Baucon, A. \& Santos, V.F., 2010. Patterns of occurrence and distribution of crustacean ichnofossils in the Lower Jurassic-Upper Cretaceous of Atlantic occidental margin basins, Portugal. Acta Geologica Polonica 60, 19-28.

Deshpande, S.V. \&Merh, S.S., 1980. Mesozoic sedimentary model of Wagad hills, Kutch, Western India. Journal of Geological Society of India 21, 75-83.

Dott Jr, R.H., 1964. Wacke, graywacke and matrix - What approach to immature sandstone classification? Journal of Sedimentary Research 34, 625-632.

Ezeh, S.C., Mode, W.A., Ozumba, B.M. \&Yelwa, N.A., 2016. Sedimentology and ichnology of Neogene Coastal Swamp deposits in the Niger Delta Basin, Nigeria. Geologos 22, 191-200.

Fisher, W.L., Brown Jr, L.F., Scott, A.J. \& McGowen, J.H., 1969. Delta Systems in the exploration for oil and gas: a research colloquium. The University of Texas at Austin, Bureau of Economic Geology, 212 pp.

Frey, R.W., Pemberton, S.G.\& Fagerstrom, J.A., 1984. Morphological, ethological and environmental significance of the ichnogenera Scoyenia and Anchorichnus. Journal of Paleontology 58, 511-528.

Fürsich, F.T. \& Oschmann, W., 1993. Shell beds as tools in basin analysis: the Jurassic of Kachchh, western India. Journal of the Geological Society 150, 169-185.

Galloway, W.E., 1975. Process framework for describing the morphologic and stratigraphic evolution of deltaic depositional systems. [In:] M.L. Broussard (Ed.): Deltas: models for exploration. Houston Geological Society, 87-98 pp.

Gluszek, A., 1998. Trace fossils from Late Carboniferous storm deposits, Upper Silesia Coal Basin, Poland. Acta Palaeontologica Polonica 43, 517-546.

Gray, A.B., Pasternack, G.B., Watson, E.B. \& Goñi, M.A., 2016. Abandoned channel fill sequences in the tidal estuary of a small mountainous, dry $\square$ summer river. Sedimentology 63, 176-206.

Hampson, G.J. \& Howell, J.A., 2017. Sedimentologic and sequence-stratigraphic characteristics of wave-dominated deltas. American Association of Petroleum Geologists Bulletin 101, 441-451.

Hansen, C.D. \& MacEachern, J.A., 2007. Application of the asymmetric delta model to along-strike facies variations in a mixed wave-and river-influenced delta lobe, Upper Cretaceous Basal Belly River Formation, central Alberta. [In:] J.A. MacEachern, S.G. Pemberton, M.K. Gingras, \& K.L. Bann (Eds): Applied Ichnol$o g y$, Society for Sedimentary Geology (SEPM), Core workshop 52, 255-271.

Harris, P.T., Baker, E.K., Cole, A.R. \& Short, S.A., 1993. A preliminary study of sedimentation in the tidally dominated Fly River Delta, Gulf of Papua. Continental Shelf Research 13, 441-472.
Higgins, S.A., Overeem, I., Steckler, M.S., Syvitski, J.P., Seeber, L. \& Akhter, S.H., 2014. InSAR measurements of compaction and subsidence in the Ganges-Brahmaputra Delta, Bangladesh. Journal of Geophysical Research: Earth Surface 119, 1768-1781.

Huang, C. \& Bhattacharya, J.P., 2017. Facies analysis and its relation to point-sourced growth faults in river-dominated prodeltaic delta front deposits of the Cretaceous Ferron Notom Delta, Utah, USA. Marine and Petroleum Geology 81, 237-251.

Hurd, T.J., Fielding, C.R. \& Hutsky, A.J., 2014. Variability in sedimentological and ichnological signatures across a river-dominated delta deposit: Peay Sandstone Member (Cenomanian) of the northern Bighorn Basin, Wyoming, USA. Journal of Sedimentary Research 84, 1-18.

Jansa, L., 1972. Depositional history of the coal-bearing upper Jurassic-lower Cretaceous Kootenay Formation, southern Rocky Mountains, Canada. Geological Society of America Bulletin 83, 3199-3222.

Jensen, S., 1997. Trace fossils from the Lower Cambrian Mickwitzia sandstone, south-central Sweden. Fossils and Strata 42, 1-110.

Knaust, D., 2013. The ichnogenus Rhizocorallium: classification, trace makers, palaeoenvironments and evolution. Earth-Science Reviews 126, 1-47.

Krishna, J., 2017. The Indian Mesozoic chronicle. Springer, Singapore. 693 pp.

Krishna, J., Pandey, B. \& Pathak, D.B., 2009. Characterization of Dichotomoceras in the Oxfordian of Kachchh. Journal of the Geological Society of India 74, 469-479.

Krishna, J., Pathak, D.B. \& Pandey, B., 1998. Development of Oxfordian (Early Upper Jurassic) in the most proximally exposed part of the Kachchh Basin at Wagad outside the Kachchh Mainland. Journal of the Geological Society of India 52, 513-522.

Kulkarni, K.G. \& Ghare, M.A., 1989. Stratigraphic distribution of ichnotaxa in Wagad region, Kutch, India. Journal of the Geological Society of India 33, 259-267.

Liu, J.P., Li, A.C., Xu, K.H., Velozzi, D.M., Yang, Z.S., Milliman, J.D. \& DeMaster, D.J., 2006. Sedimentary features of the Yangtze River-derived along-shelf clinoform deposit in the East China Sea. Continental Shelf Research 26, 2141-2156.

Liu, J.P., Xu, K.H., Li, A.C., Milliman, J.D., Velozzi, D.M., Xiao, S.B. \& Yang, Z.S., 2007. Flux and fate of Yangtze River sediment delivered to the East China Sea. Geomorphology 85, 208-224.

MacEachern, J.A., Pemberton, S.G., Gingras, M.K. \& Bann, K.L., 2007. The ichnofacies paradigm: a fifty-year retrospective. [In:] Miller, W. (Ed.): Trace fossils concepts, problems, prospects. Elsevier. 52-77 pp.

Maguregui, J. \& Tyler, N., 1991. Evolution of middle Eocene tide-dominated deltaic sandstones, Lagunillas Field, Maracaibo Basin, western Venezuela. [In:] A.D. Miall \& N. Tyler (Eds): The three-dimensional facies architecture of terrigenous clastic sediments and its implications for hydrocarbon discovery and recovery. Society for Sedimentary Geology (SEPM) 3, 233-244. 
Mallik, J., Mathew, G. \& Greiling, R.O., 2009. Magnetic fabric variations along the fault related anticlines of Eastern Kachchh, Western India. Tectonophysics 473, 428-445.

Mandal, P., Rastogi, B.K., Satyanaraya, H.V.S., Kousalya, M., Vijayraghavan, R., Satyamurty, C. \& Kumar, N., 2004. Characterization of the causative fault system for the 2001 Bhuj earthquake of Mw 7.7. Tectonophysics 378, 105-121.

Mangano, M.G. \& Buatois, L.A., 1999. Ichnofacies models in Early Paleozoic tide-dominated quartzites: onshore-offshore gradients and the classic Seilacherian paradigm. Acta Universitatis Carolinae Geologica 1/2, 151-154.

Mángano, M.G. \& Buatois, L.A., 2004. Reconstructing early Phanerozoic intertidal ecosystems: Ichnology of the Cambrian Campanario Formation in northwest Argentina. Fossils and Strata 51, 17-38.

McIlroy, D., 2004. Ichnofabrics and sedimentary facies of a tide-dominated delta: Jurassic Ile Formation of Kristin Field, Haltenbanken, offshore Mid-Norway. Geological Society of London Special Publications 228, 237272.

Miall, A.D., 2006. Methods of architectural-element analysis. The Geology of Fluvial Deposits. Springer, Berlin, pp. 75-98.

Mishra, D. \& Biswas, S.K., 2009. Sedimentology, sequence stratigraphy and syn-rift model of younger part of Washtawa Formation and early part of Kanthkot Formation, Wagad, Kachchh basin, Gujarat. Journal of the Geological Society of India 73, 519-527.

Mount, J., 1985. Mixed siliciclastic and carbonate sediments: a proposed first-order textural and compositional classification. Sedimentology 32, 435-442.

Patruno, S., Hampson, G.J. \& Jackson, C.A., 2015. Quantitative characterisation of deltaic and subaqueous clinoforms. Earth-Science Reviews 142, 79-119.

Pemberton, S.G. \& Frey, R.G., 1982. Trace fossils nomenclature and the Planolites-Palaeophycus dilemma. Journal of Paleontology 56, 843-881.

Pettijohn, F.J., 1949. Sedimentary Rocks. Harper and Brothers, New York, 526 pp.

Rai, J., Garg, S., Gupta, M., Singh, A., Pandey, D.K., Fürsich, F.T., Alberti, M. \& Garg, R., 2015. Integrated biostratigraphy of the Jurassic strata of the Wagad
Uplift, Kachchh, western India. Volumina Jurassica 13, 55-80.

Rastogi, B.K., 2001. Ground deformation study of Mw 7.7 Bhuj earthquake of 2001. Episodes 24, 160-165.

Reijers, T., 2011. Stratigraphy and sedimentology of the Niger Delta. Geologos 17, 133-162.

Sanders, D., Lukesch, M., Rasser, M. \& Skelton, P., 2007. Shell beds of diceratidrudists ahead of a low-energy gravelly beach (Tithonian, Northern Calcareous Alps, Austria): Palaeoecology and Taphonomy. Austrian Journal of Earth Sciences 100,186-199.

Schomacker, E.R., Kjemperud, A.V., Nystuen, J.P. \& Jahren, J.S., 2010. Recognition and significance of sharp-based mouth-bar deposits in the Eocene Green River Formation, Uinta Basin, Utah. Sedimentology 57, 1069-1087.

Simões, M.G. \& Kowalewski, M., 1998. Shell beds as paleoecological puzzles: a case study from the Upper Permian of the Paraná Basin, Brazil. Facies 38, 175-195.

Singh, N.P., 2006. Mesozoic lithostratigraphy of the Jaisalmer Basin, Rajasthan. Journal of the Palaeontological Society of India 51, 1-25.

Van Straaten, L.M.J.U. \& Kuenen, Ph.H., 1958. Tidal action as a cause of clay accumulation. Journal of Sedimentary Petrology 28, 406-413.

Vossler, S.M. \& Pemberton, S.G., 1988. Skolithos in the Upper Cretaceous Cardium Formation: an ichnofossil example of opportunistic ecology. Lethaia 21, 351-362.

Willis, B.J. \& Gabel, S., 2001. Sharp-based, tide-dominated deltas of the Sego Sandstone, Book Cliffs, Utah, USA. Sedimentology 48, 479-506.

Worsley, D. \& Mørk, A., 2001. The environmental significance of the trace fossil Rhizocoralliumjenense in the Lower Triassic of western Spitsbergen. Polar Research 20, 37-48.

Zhu, X., Zeng, H., Li, S., Dong, Y., Zhu, S., Zhao, D. \& Huang, W., 2017. Sedimentary characteristics and seismic geomorphologic responses of a shallow-water delta in the Qingshankou Formation from the Songliao Basin, China. Marine and Petroleum Geology 79, 131-148.

Manuscript submitted 28 December 2017 Revision accepted 25 June 2018 